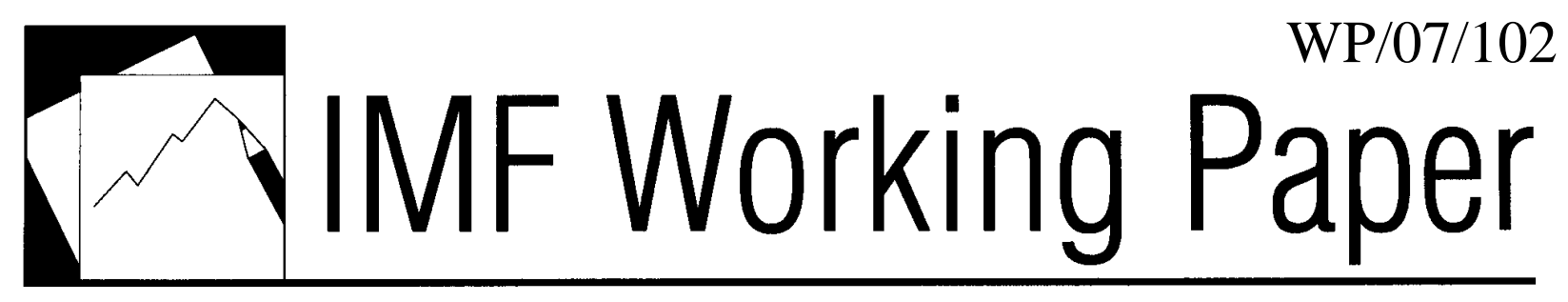

\title{
Diagnosing Dutch Disease: \\ Does Russia Have the Symptoms?
}

Nienke Oomes and Katerina Kalcheva 



\title{
IMF Working Paper
}

\author{
Middle East and Central Asia Department
}

\section{Diagnosing Dutch Disease: Does Russia Have the Symptoms?}

\author{
Prepared by Nienke Oomes and Katerina Kalcheva ${ }^{1}$ \\ Authorized for distribution by John Wakeman-Linn
}

April 2007

\begin{abstract}
This Working Paper should not be reported as representing the views of the IMF. The views expressed in this Working Paper are those of the author(s) and do not necessarily represent those of the IMF or IMF policy. Working Papers describe research in progress by the author(s) and are published to elicit comments and to further debate.

In this paper, we assess whether recent economic developments in Russia are symptomatic of Dutch Disease. We first provide a brief review of the literature on Dutch Disease and the natural resource curse. We then discuss the symptoms of Dutch Disease, which include (1) real exchange rate appreciation; (2) slower manufacturing growth; (3) faster service sector growth; and (4) higher overall wages. We test these predictions for Russia while carefully controlling for other factors that could have led to similar symptoms. We conclude that, while Russia has all of the symptoms, the diagnosis of Dutch Disease remains to be confirmed.

JEL Classification Numbers: F30, P28, Q30

Keywords: Dutch Disease, Russia, oil, real exchange rate, transition

Author's E-Mail Address:noomes@imf.org; katerina.kalcheva@morganstanley.com

\footnotetext{
${ }^{1}$ For valuable comments and suggestions, we are grateful to Balázs Égert, Lorenzo Figliuoli, Ikka Korhonen, Mwanza Nkusu, Jouko Rautava, Lucio Vinhas de Souza, Harm Zebregs, and participants in seminars held at the International Monetary Fund (IMF) and at the Bank of Finland. Any opinions expressed within this article are those of the authors acting in a personal capacity and do not necessarily represent the views of Morgan Stanley. This paper is also forthcoming in the journal Emerging Markets Letters.
} 


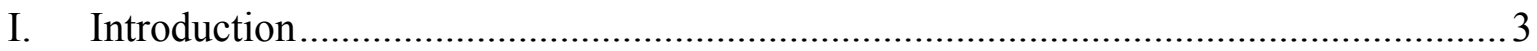

II. Explaining the Natural Resource Curse ............................................................5

III. Evidence of Dutch Disease in Russia ................................................................ 10

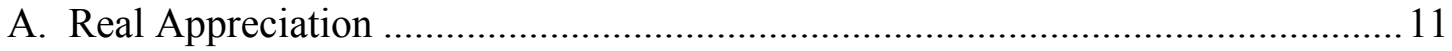

B. Manufacturing Sector Decline and Service Sector Growth ................................ 16

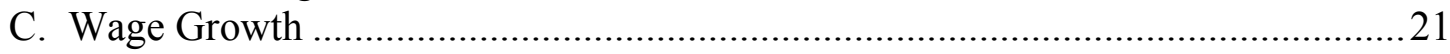

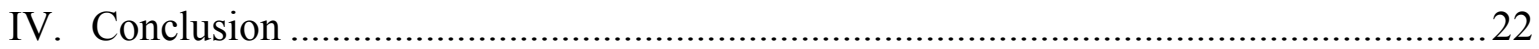

Figures

1. Oil Production and Export of Crude Oil, 1995-2005 ........................................... 4

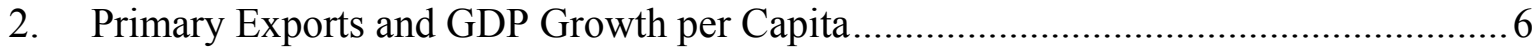

3. Real Effective Exchange Rate and Its Determinants, 1995-2005 ............................ 15

4. Estimated Real Exchange Rate Misalignment, 1997-2005 ...................................... 16

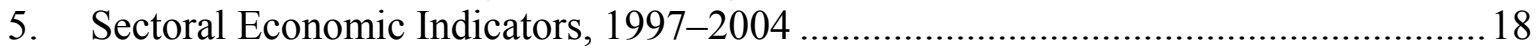

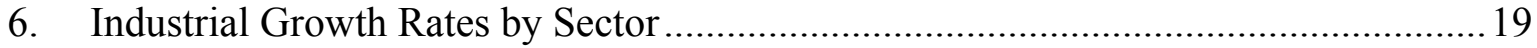

Tables

1. Summary of Dutch Disease Symptoms .............................................................. 9

2. Real Exchange Rate Determinants: Estimated Cointegrating Vectors ...................... 12

3. Real Effective Exchange Rate and Its Determinants: Estimated Cointegrating

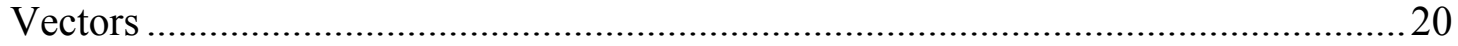

Appendix

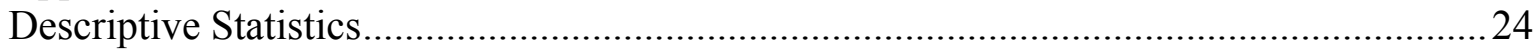

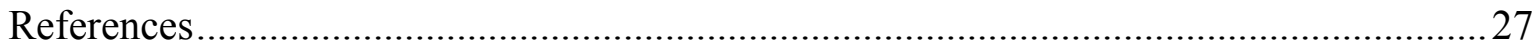




\section{INTRODUCTION}

Russia is one of the major producers of natural resources. It is estimated to hold the world's largest natural gas reserves, second-largest coal reserves, and seventh-largest oil reserves. $^{2}$ In 2005, Russia was the world's largest producer and exporter of natural gas and the second-largest producer and exporter of crude oil. ${ }^{3}$

Oil and gas exports have contributed significantly to recent output growth in Russia. Crude oil, oil products, and gas together account for almost 60 percent of Russia's total export revenues, ${ }^{4}$ and for an estimated 20-25 percent of Russia's gross domestic product (GDP). ${ }^{5}$ In recent years, record high oil prices have generated significant windfall revenues, have put the real exchange rate on an appreciation path, and have stimulated the economy to the point of overheating (Oomes and Dynnikova, 2006).

\section{However, in spite of record high oil prices, crude oil output and export growth have recently slowed significantly (Figure 1). In 2005 and 2006, oil output grew by only about} $2 \frac{1}{2}$ percent year-on-year, following much higher growth rates of around 10 percent in both 2003 and 2004. There are several reasons for the slowdown. First, the recent increase in state ownership created significant uncertainty in the sector. Second, increases in oil sector taxation and bottlenecks in the distribution network have raised production and transportation costs. Third, there appear to be diminishing returns to existing oil extraction, implying that further growth is possible only with significant new investment in the exploration and development of new fields and the necessary export infrastructure.

\footnotetext{
${ }^{2}$ The International Energy Agency (2005) estimates that Russia has the world's largest proven natural gas reserves at 48 trillion cubic meters (tcm), followed by Iran (28 tcm), Qatar (26 tcm), and Saudi Arabia $(6.7 \mathrm{tcm})$. As such, Russia is estimated to hold around 30 percent of the world's proven gas reserves, of which Gazprom has half. According to the Russian reserve classification, total potential gas reserves (including unproven reserves) are almost five times higher.

${ }^{3}$ According to the International Energy Agency (2005), Russia and Saudi Arabia were the world's leading oil producers, while Saudi Arabia was the leading exporter of oil.

${ }^{4}$ According to the International Monetary Fund (2005, Table 25), crude oil constituted 32 percent of total exports in 2005, oil products 11 percent, gas 12 percent, and coal less than 2 percent.

${ }^{5}$ Official Rosstat data substantially underestimate the share of oil and gas in GDP, due to transfer pricing. The World Bank (2004, chapter II; and 2005a, section C3) and Gurvich (2004) correct for this problem in different ways, but both end up with estimates of about 20 percent for 2000 and 2003, respectively. This share is likely to have increased somewhat in recent years. Ahrend (2006) also corrects for transfer pricing and finds that the role of the oil sector, and particularly privately owned oil companies, has been vastly more important in driving economic growth than thus far recognized.
} 
Figure 1. Russia: Oil Production and Export of Crude Oil,

(1995-2005)

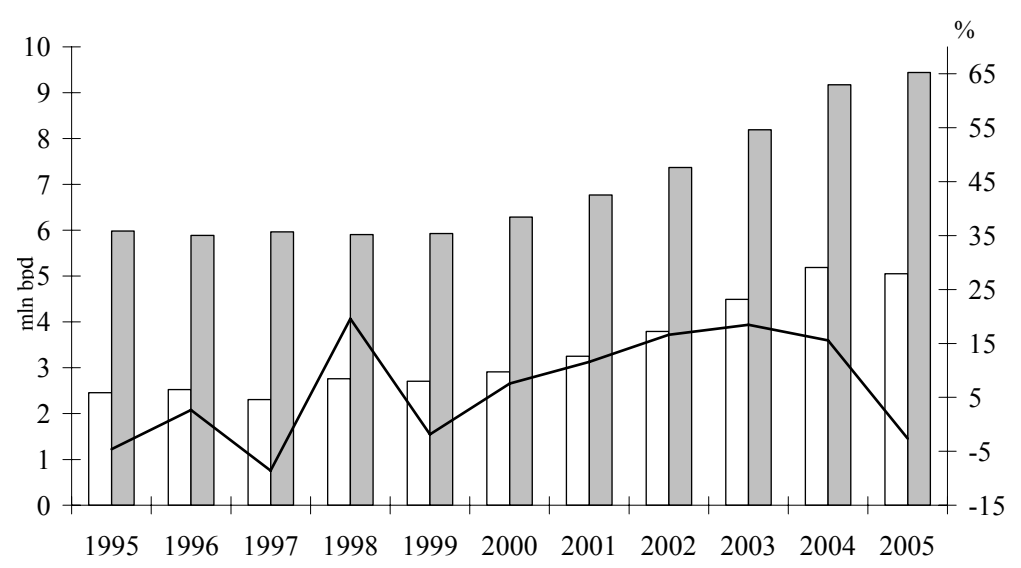

$\square$ Export of crude oil, mln. bpd $\square$ Oil production, mln. bpd $\quad$ - Export annual change,\%

In addition to the constraints on fuel sector growth, the experience of other resourcerich countries suggests that natural resource wealth may lead to lower growth in the non-resource sector as well. The notion that there may be such a "natural resource curse" is based on the empirical finding that resource-rich economies, on average, experience lower growth rates than resource-poor economies (Sachs and Warner, 1995, 2001). One explanation for this is that the large windfall revenues from natural resources tend to give rise to rent-seeking behavior and fights over the distribution of these revenues, which in turn impede growth, as productive resources are drawn into non-productive activities. A second explanation is that resource rents tend to be volatile, which is bad for growth. A third explanation - the one we will focus on in this paper-is that of "Dutch Disease," the hypothesis that windfall revenues from natural resources give rise to real exchange rate appreciation, which in turn reduces the competitiveness of the manufacturing sector. ${ }^{6}$

Opinions are still divided as to whether the Russian economy has been suffering from Dutch Disease. A detailed analysis by Westin (2004), based on data through 2003, concluded that, despite the existence of some Dutch Disease symptoms, Russia had not contracted the full-blown disease by end-2003. Similarly, Roland (2005) argued that it is premature to conclude that the Russian economy is experiencing Dutch Disease. However, Standard and Poor's $(2005,2006)$ warned that Russia is "fast becoming a classical victim", and must avoid the "hydrocarbons habit" in order to sustain high sovereign ratings. ${ }^{7}$ Moreover, a study by the World Bank (2005b) found that ruble appreciation had led to a

\footnotetext{
${ }^{6}$ There have been few studies on Dutch Disease in other oil-producing countries. Kutan and Wyzan (2005) find that significant Dutch Disease symptoms are present in Kazakhstan. Egert and Leonard (2006) find less significant Dutch Disease symptoms but find support for the hypothesis that the real exchange rate in Kazakhstan has appreciated as a result of the oil revenues.

${ }^{7}$ In 2006, Standard \& Poors raised Russia's sovereign credit rating to BBB + , while Moody's assigned a Baa2 credit rating.
} 
slowdown in many manufacturing industries, which it argued is consistent with the symptoms of Dutch Disease. Latsis (2005) went even further and argued that "Russia has all the classical symptoms of Dutch Disease."

This paper contributes to the debate by precisely defining the symptoms of Dutch Disease and testing whether the Russian economy had each of the symptoms. In Section II, we provide a brief literature review and explain the link between Dutch Disease and the natural resource curse. In Section III, using our econometric model, we test for the main symptoms of Dutch Disease, which include (1) real appreciation, (2) a slowdown in manufacturing growth, (3) an acceleration in service sector growth (provided the spending effect dominates the resource movement effect), and (4) an increase in the overall wage level.

We find that, while Russia appears to have the symptoms, we cannot conclude with certainty that it has contracted Dutch Disease. Regarding the first symptom, we find evidence that higher oil prices have led to faster real appreciation but no evidence of an overvalued real exchange rate. Regarding the second and third symptoms, we find evidence that the manufacturing sector has declined relative to the service sector, but this could as well be the result of a "transition effect." Finally, while real wages have increased rapidly in all sectors, this might also be explained by other factors, such as de-shadowization, rapid productivity growth, and a rebound from the 1998 crisis. We therefore conclude that further research is needed in order to better control for these other factors.

\section{Explaining The Natural Resource Curse}

The "natural resource curse" hypothesis is based on the observation that resource-rich economies grow slower, on average, than resource-poor economies. For example, many natural resource-rich countries, such as Nigeria, Venezuela, Angola, and Ecuador, have failed to prosper during the past few decades, while resource-poor countries in Asia have enjoyed rapid economic growth. In a well-known paper, Sachs and Warner (1995) report a robust negative relationship between real GDP growth per capita and the ratio of resource exports to GDP in a sample of 97 developing countries during the period 1970-1989. This negative relationship is illustrated in Figure 2, which replicates Sachs and Warner's basic chart and updates it for 1970-2000. ${ }^{9}$ This surprising result has been shown to hold for a variety of measures of resource abundance and to be robust to controlling for other possible growth

\footnotetext{
${ }^{8}$ Dutch Disease was also debated at the World Economic Forum in Moscow in 2005, where the economy minister assured the audience that the Russian government was aware of the resource curse and that full efforts were being directed toward limiting the effects. At the same forum, Sergei Guriev of the Centre for Economic and Financial Research in Russia argued that Dutch Disease, as it applies to Russia, is "more a policy phenomenon since policy-makers centre their strategy on oil and ignore investment in other areas such as healthcare and education." See http://www.weforum.org/site/homepublic.nsf/Content/Report+Russia+2005++ theme +2

${ }^{9}$ Following Sachs and Warner (1995), resource exports are defined here as "primary exports," which are measured as the sum of the categories "non-fuel primary products" and "fuels" in the United Nations Comtrade database.
} 
determinants, such as initial per capita income, trade policy, government efficiency, and investment rates. $^{10}$

Figure 2. Primary Exports and GDP Growth per Capita

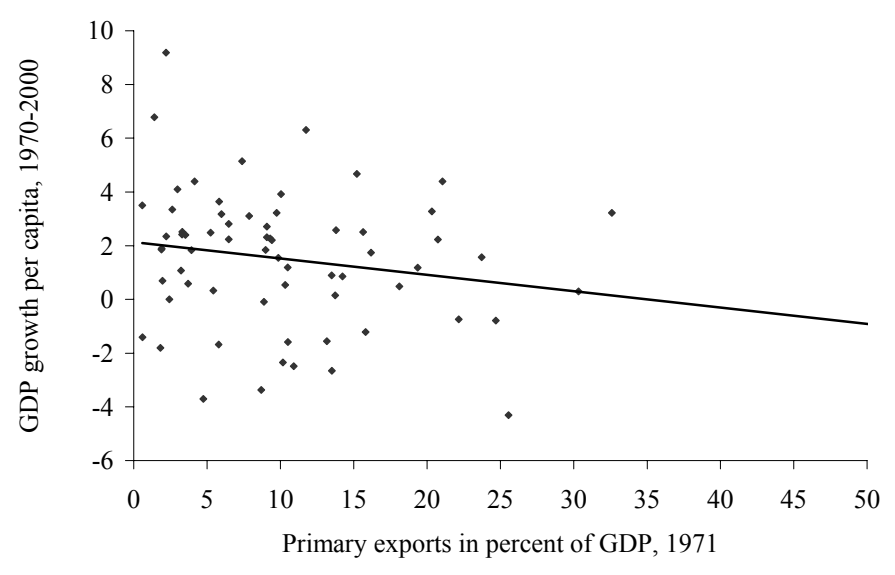

Sources: Penn World Tables, International Financial Statistics, and U.N. Comtrade database.

\section{One possible explanation for the natural resource curse is that resource wealth tends to give rise to a fight over existing resources, which in turn leads to poor institutional quality and lower growth. The argument here is that the large rents that can be obtained} from natural resources create incentives for governments and private agents to engage in rent-seeking behavior, "voracity," 11 corruption, ${ }^{12}$ or even civil conflict, ${ }^{13}$ thus crowding out entrepreneurial activity and other pro-growth activities. Incentives for rent seeking arise when the expected net payoffs from engaging in unproductive activities to appropriate the existing wealth (e.g., corruption, conflict) exceed the net payoffs from engaging in productive activities to create wealth. Hausmann and Rigobon (2003) argue that the presence of common-pool problems or uncertainty related to property rights over the resource income leads to inefficient fights over existing resources, which can generate lower growth. Sala-i-

\footnotetext{
${ }^{10}$ Sachs and Warner (2001) show that the negative relationship also holds up when controlling for omitted variables, proxied by lagged growth rates. They, therefore, conclude that the natural resource curse is not just a statistical mirage that results, e.g., from the fact that natural resources may be the only surviving sector in countries that have grown more slowly for other reasons. Similar empirical results are reported in Gylfason and others (1999). In addition, Gylfason (2004) finds that natural resource dependence is negatively correlated with trade, foreign investment, domestic investment, equality, political liberty, education, and financial depth.

${ }^{11}$ The voracity effect, coined by Lane and Tornell (1996) and Tornell and Lane (1999), refers to a more-thanproportionate increase in fiscal redistribution following a terms-of-trade windfall.

${ }^{12}$ On corruption, see, e.g., Mauro (1995) and Leite and Weidmann (1999). Gylfason (2004) finds empirically that natural resource dependence is positively related with corruption.

${ }^{13}$ Collier and Hoeffler (2004) find a strong and nonlinear effect of the share of natural resources in GDP on the probability of civil conflict in a country.
} 
Martin and Subramanian (2003) call this the "institutional impact of natural resources," and find empirical evidence that some natural resources (in particular, oil and minerals) exert a robust negative and nonlinear impact on growth via their deleterious impact on institutional quality. ${ }^{14}$ In a similar study, Isham and others (2005) find that countries that export fuels, minerals, plantation crops, and coffee or cocoa do worse across an array of governance indicators, even when controlling for other potential determinants of governance.

A second explanation for the natural resource curse is that resource rents tend to be volatile. This volatility arises in part from the fact that natural resources typically have low price elasticities of supply. Volatility, in turn, has been shown to be negatively correlated with growth (Ramey and Ramey, 1995) and investment (Aizenman and Marion, 1999), including investment in education (Flug, Spilimbergo, and Wachtenheim, 1998). ${ }^{15}$ Hausmann and Rigobon (2003) argue that the main reason for this negative effect is the existence of financial market imperfections, as a result of which volatility leads to a higher cost of capital, lower investment, and lower welfare.

This paper focuses on a third explanation of the resource curse, which is the hypothesis commonly known as Dutch Disease. Going back to Corden (1982) and Corden and Neary (1984), the Dutch Disease hypothesis is briefly summarized as the notion that an exogenous increase in resource prices or in resource output ${ }^{16}$ results in real exchange rate appreciation and a decline in the manufacturing sector. ${ }^{17}$ Under certain conditions, which we will describe below, this can lead to lower long-run growth.

To explain the basic Dutch Disease model, we group the goods produced by the economy into three categories: natural resources (which we refer to as "oil"), non-

\footnotetext{
${ }^{14}$ Sala-i-Martin and Subramanian (2003) argue that waste and poor institutional quality stemming from oil, rather than Dutch Disease, appear to have been primarily responsible for Nigeria's poor long-run economic performance. From 1965 to 2000, Nigeria accumulated oil revenues of US\$350 billion at constant 1995 prices. Nevertheless, the population living with less than one U.S. dollar per day increased from about 36 percent in 1970 to just under 70 percent in 2000 .

${ }^{15}$ However, there are also studies that have found a positive correlation between volatility and growth (see, e.g., Caballero,1991).

${ }^{16}$ Dutch Disease is sometimes interpreted as exclusively resulting from the discovery of new natural resources, which characterized the original Dutch case that gave the disease its name. For example, the Rutherford Dictionary of Economics gives the following definition of Dutch Disease: "The harmful consequences for a national economy of discovering natural resources, especially the decline in traditional industries brought about by the rapid growth and prosperity of a new industry. The successful new industry has high exports, creating a foreign exchange surplus and raising the country's exchange rate with the consequence that other industries of the economy become internationally uncompetitive" (Rutherford, 1992). Buiter and Purvis (1983) distinguish between the case of oil price increases, which have a temporary effect, and the case of oil discoveries, which have permanent effects.

${ }^{17}$ Dutch Disease can also be caused by foreign exchange inflows in the form of international aid or loans. On Dutch Disease and aid, see, e.g., Younger (1992), Bulir and Lane (2002), Adam and Bevan (2003), Nkusu (2004), or Rajan and Subramanian (2005).
} 
resource tradable goods (which we refer to as "manufacturing"), and nontradable goods (which we refer to as "services"). By definition, tradable goods (oil and manufacturing) are subject to international competition; hence, their prices are determined by world demand and supply, and it is assumed that the country is small enough so as not to be able to influence these prices. ${ }^{18}$ Services, on the other hand, are not subject to international competition, and therefore their prices depend only on domestic demand and supply.

The predictions of the Dutch Disease model are summarized in Table 1, which, following Corden and Neary (1984), distinguishes between a resource movement effect and a spending effect. Assuming that the supply of oil is not perfectly inelastic, a rise in the oil price increases the demand for labor and capital in the oil sector, which leads to higher wages there and to a higher return on capital. If factors are mobile, this will induce labor and capital to move from the manufacturing and service sectors to the oil sector. Oil sector output and employment will thus increase, while output and employment in manufacturing and services will decline. Corden and Neary (1984) refer to this fall in manufacturing output as "direct de-industrialization." While the price of manufacturing goods does not change, because it is determined abroad, the decline in services output leads to excess demand for services and therefore to an increase in the price of services. The result is an increase in the price of nontradables relative to tradables, inducing an appreciation of the real exchange rate.

While the resource movement effect is unlikely to be important in Russia, the spending effect is likely to be important. The resource movement effect only occurs if factors are sufficiently mobile between the oil and non-oil sectors, which is unlikely in Russia given that the oil sector employs relatively few workers and labor mobility is low in general (as documented, e.g., by Andrienko and Guriev, 2004). However, the spending effect obtains regardless of whether the oil sector employs any labor at all. The spending effect occurs simply because higher oil prices generate higher wages and/or profits in the oil sector, thus raising aggregate demand in the economy. To the extent some of this demand goes into domestically produced services, prices of services will rise, whereas the prices of oil and manufacturing goods, being determined abroad, are not affected. This again induces real exchange rate appreciation. ${ }^{19}$ If labor is completely immobile, then the supply of services does not change and the only effect of a shift in demand is an increase in the relative price of services. However, if labor is mobile between the manufacturing and service sectors, which is to an extent the case in Russia, then an upward shift in the demand for services will lead to an increase in the supply of services and in the demand for labor in the service sector and thus push up wages in the service sector. This will encourage workers to move from the manufacturing and oil sectors to the service sector, thus forcing manufacturing and oil firms

\footnotetext{
${ }^{18}$ In fact, some models of Dutch Disease assume that domestic agents do not consume the tradable goods produced in their own country, but only consume non-tradables and imported tradables (e.g., De Gregorio and Wolf, 1994).

${ }^{19}$ If the nominal exchange rate is fixed, this real appreciation will take the form of inflation. However, if the nominal exchange rate appreciates enough to eliminate windfall profits in the oil sector, the spending effect will not take place (or will be directed at imports rather than domestic goods), but there would be an equivalent amount of real appreciation, this time in the form of nominal appreciation.
} 
to raise their wages as well. ${ }^{20}$ Since they cannot compensate by raising their prices, they will see their profits fall and will have to downsize. The resulting drop in manufacturing output and employment is referred to by Corden and Neary (1984) as "indirect de-industrialization."

Table 1. Summary of Dutch Disease Symptoms

\begin{tabular}{|c|c|c|c|c|}
\hline & Output & Employment & Wage & Price \\
\hline \multicolumn{5}{|l|}{ Resource movement effect } \\
\hline oil sector & + & + & + & given \\
\hline manufacturing sector & - & - & + & given \\
\hline services sector & - & - & + & + \\
\hline \multicolumn{5}{|l|}{ Spending effect } \\
\hline oil sector & - & - & + & given \\
\hline manufacturing sector & - & - & + & given \\
\hline services sector & + & + & + & + \\
\hline \multicolumn{5}{|l|}{ Combined effect } \\
\hline oil sector & indeterminate & indeterminate & + & given \\
\hline manufacturing sector & - & - & + & given \\
\hline services sector & indeterminate & indeterminate & + & + \\
\hline
\end{tabular}

Combining the two effects, the Dutch Disease hypothesis generates four predictions. First, since the relative price of services increases, the real exchange rate appreciates. Second, there is an unambiguous decline in manufacturing output and employment, reflecting both direct and indirect de-industrialization. Third, the combined effects on output and employment in the oil sector and the service sector are ambiguous, because the spending and resource movement effects pull in opposite directions here. However, if the oil sector employs relatively few workers or if labor mobility is low, as in Russia, it is to be expected that the spending effect will dominate the resource movement effect, in which case we would also expect to see an increase in service sector output and employment. Fourth, if labor is mobile, the overall wage level will increase.

It is not obvious, however, that Dutch Disease can explain the natural resource curse. During times of high oil prices, it is only natural, and in fact optimal, for resources to move out of the manufacturing sector and into the oil and service sectors. If oil prices were to stay high forever, would it not be optimal to specialize in oil and eliminate the manufacturing sector altogether?

One reason why de-industrialization may lead to lower growth is that it implies increased volatility. As Hausmann and Rigobon (2003) point out, the smaller the manufacturing sector, the more difficult it is for the economy to absorb shocks via labor

\footnotetext{
${ }^{20}$ For simplicity, it is assumed that skill levels in all sector are similar, so that, under perfect labor mobility, wages in all sectors are always equal in equilibrium.
} 
mobility. In the extreme case, if the oil sector employs no labor and the manufacturing sector disappears forever, the service sector will be the only employer, and all shocks will have to be absorbed by expenditure switching and unemployment, implying increased volatility. As argued above, this implies lower growth as long as financial markets are imperfect. However, it does not explain why growth would be permanently lower. That is, why could the manufacturing sector not be rebuilt during times of low oil prices?

\section{The main reason why Dutch Disease may lead to permanently lower growth is that manufacturing sectors tend to be more competitive and innovative than other sectors and are characterized by technological spillovers. First, due to the absence of large rents, manufacturing firms typically have lower concentration ratios and face more competition than natural resource firms, which improves their efficiency. Second, due to the nature of the manufacturing process, there is more scope for technological progress in manufacturing than in resource extraction or in services (except perhaps for information technology and financial services). Finally, manufacturing sectors tend to include more vertical and horizontal spillovers (within and between firms) from technological progress than do natural resource sectors. Without the existence of such technological spillovers, such as "learning by doing," it would be difficult to explain why a temporary contraction in the manufacturing sector could have permanent effects on growth. ${ }^{21}$}

\section{EVIDENCE OF DUTCH Disease IN RUSSIA}

In this section, we test whether the four symptoms of Dutch Disease can be observed in Russia. In order to avoid a spurious diagnosis, however, it is important to control for other factors that may have induced the same symptoms. For example, while it is clear that the Russian real effective exchange rate has appreciated substantially in recent years, this by itself cannot be regarded as evidence of Dutch Disease, since the real exchange rate may have appreciated for other reasons. We therefore ask whether the effect of oil prices on the real effective exchange rate is significantly positive after controlling for other real exchange rate determinants, including government consumption, net international reserves, the productivity differential, and corruption. Similarly, it is not difficult to show that the manufacturing sector grew more slowly than the service sector and that wage growth was rapid in recent years. However, when we correct for other factors that could have led to these phenomena, we cannot unequivocally conclude that these symptoms in fact are the result of Dutch Disease.

\footnotetext{
${ }^{21}$ In a theoretical model of learning-by-doing, Krugman (1997) shows that, once manufacturing industries are crowded out and move abroad, it is very difficult to bring them back when the favorable conditions for resource exports are exhausted. However, Torvik (2001) shows that, if both tradable and non-tradable sectors can contribute to learning, and if there are learning spillovers between them, a foreign exchange gift results in a real exchange rate depreciation in the long run, due to a shift in steady-state relative productivity between the tradable and non-tradable sectors.
} 


\section{A. Real Appreciation}

Using a Behavioral Equilibrium Exchange Rate (BEER) model, we estimate the empirical long-run relationship between the real exchange rate and its determinants, after which we interpret the error correction term as the deviation from the long run equilibrium, that is, as the extent of exchange rate misalignment. Appendix I reports evidence of stable cointegration relationships between the real exchange rate, the oil price, the productivity differential, government consumption, net international reserves (NIR), and the corruption index. Although our dataset covers the period January 1995-December 2005, we are only able to obtain robust results when excluding the somewhat unstable period of 1995-1996. The data, including their sources and their correlation matrix, are described in Appendix I, Tables A1 and A2. Table A3 shows that all variables are nonstationary, ${ }^{22}$ implying that it is legitimate to search for a cointegration relationship. Table A4 shows the results of Johansen cointegration tests, which provide evidence that a unique cointegrating vector exists between various combinations of the variables. ${ }^{23}$

Table 2 summarizes our estimated cointegrating vectors, with the coefficient for the real exchange rate normalized to one. We estimate three different cointegrating vectors, including three, four, and five explanatory variables, respectively. Our baseline regression, obtained by minimizing the Akaike information criterion and maximizing the loglikelihood, is equation (2) at the center column of Table 2, which contains all variables controlled for, except the corruption index. All coefficient estimates in this equation are statistically significant and have the expected signs.

Subject to the usual caveats regarding the difficulty of estimating a long-run relationship for a sample period of less than ten years for an economy in transition, our estimates seem unbiased and robust. As Table 2 shows, the residuals are generally wellbehaved, in that there is no evidence of serial correlation or non-normality. Only in equation (1) is there some evidence of heteroskedasticity, as the hypothesis of no heteroskedasticity is rejected only at the 8-percent significance level. Comparing the baseline coefficient estimates in equation (2) with those in equations (1) and (3) shows that the coefficient estimates are generally robust to exclusion and inclusion of additional variables. ${ }^{24}$

\footnotetext{
22 That is, the null hypothesis of a unit root in levels cannot be rejected in most cases (with sufficient lags), while the null hypothesis of a unit root in differences can be rejected.

${ }^{23}$ Specifications (1), (2), and (3) in Appendix Table A4 correspond to those in Table 2.

${ }^{24}$ In order to further check robustness, we also conducted a Chow breakpoint test, as well as short-run causality and long-run weak exogeneity tests. The Chow forecast test with search over data points shows that there is no significant structural break at the 5-percent significance level, thus providing evidence for the stability of the model. The causality test indicates no evidence of short-run causality and the test for weak exogeneity on the alpha parameters suggests that none of the included variables is weakly exogenous. Details are available from the authors upon request.
} 
Table 2. Real Exchange Rate Determinants: Estimated Cointegrating Vectors

\begin{tabular}{lccc}
\hline & $\mathbf{( 1 )}$ & $\mathbf{( 2 )}$ & $\mathbf{( 3 )}$ \\
\cline { 2 - 4 } & & & \\
First observation & $1997: 04$ & $1997: 04$ & $1997: 04$ \\
Last observation & $2005: 12$ & $2005: 12$ & $2005: 12$ \\
Number of observations & 104 & 104 & 104 \\
& & & \\
Ln (oil price) & $\mathbf{0 . 5 8}$ & $\mathbf{0 . 4 9}$ & $\mathbf{0 . 5 0}$ \\
$\quad$ standard error & $(0.12)$ & $(0.13)$ & $(0.15)$ \\
Ln (government consumption) & $\mathbf{1 . 3 2}$ & $\mathbf{1 . 5 0}$ & $\mathbf{1 . 6 2}$ \\
$\quad$ standard error & $(0.20)$ & $(0.19)$ & $(0.18)$ \\
Ln (NIR) & $\mathbf{- 0 . 1 1}$ & $\mathbf{- 0 . 1 8}$ & $\mathbf{- 0 . 1 4}$ \\
$\quad$ standard error & $(0.03)$ & $(0.04)$ & $(0.03)$ \\
Ln (productivity differential) & & $\mathbf{1 . 0 8}$ & $\mathbf{0 . 9 0}$ \\
$\quad$ standard error & & $(0.36)$ & $(0.42)$ \\
Ln (corruption) & & & -0.53 \\
$\quad$ standard error & & & $(0.36)$ \\
& & & \\
LM test for serial correlation & 0.69 & 0.73 & 0.52 \\
Jarque-Bera normality test & 0.12 & 0.82 & 0.81 \\
Heteroskedasticity test & 0.08 & 0.53 & 0.92 \\
Akaike Information Criterion & -5.49 & -5.52 & -5.46 \\
Log likelihood & 305 & 311 & 311 \\
\hline
\end{tabular}

Notes: The dependent variable is the log of the real effective exchange rate. All regressions include four lags, a constant, and two dummies for September and October 1998 to control for the large real depreciation following the Russian financial crisis. Statistically significant estimates are indicated in bold.

The estimates provide suggestive evidence that higher oil prices imply real appreciation, as predicted by the Dutch Disease hypothesis. Since all variables are in logs, the coefficients can be interpreted as long-run elasticities. This means that a one percent increase in the oil price, according to our baseline estimate, leads to an approximate 0.50 percent real appreciation. ${ }^{25}$ Spatafora and Stavrev (2003) find a somewhat lower long-run elasticity $(0.31)$ for the oil price in the period 1995-2002. However, their standard error (0.12) is similar to ours, implying that the two estimates are not statistically significantly different. Nevertheless,

\footnotetext{
${ }^{25}$ Thus, the increase in the Urals oil price by 75 percent in 2005 (from an average price of US\$34.3 per barrel in 2004 to US\$60 in 2005) would, all else equal, have led to $0.5 * 75$ or 37.5 percent real appreciation. In fact, the officially published real effective ruble appreciation in 2005 was considerably less than that $(8.5$ percent according to the IFS measure), probably owing to a combination of "fiscal sterilization" (a reduction in government consumption) and "monetary sterilization" (an increase in reserve accumulation), as suggested below.
} 
it is likely that the elasticity with respect to the oil price has increased over time, given that the volume of oil exports has increased (Sosunov and Zamulin, 2006a). ${ }^{26}$

\section{Our estimates also suggest that the real exchange rate appreciates when government consumption rises as a share of GDP, implying that a reduction in government consumption can help to offset real appreciation pressures from higher oil prices. We} find that a one percent increase in the ratio of general government consumption to GDP leads to an approximate 1.5 percent real appreciation; an effect that is three times stronger than that of oil prices. The intuition behind this is that, unless governments consume only imported goods, an increase in government consumption is likely to lead to a rise in the relative price of nontradables, and therefore to real appreciation. ${ }^{27}$ This finding suggests that a reduction in government consumption can contribute substantially to limiting real appreciation. The Russian authorities' policy of saving a large part of the windfall oil and gas tax revenues in a stabilization fund since 2004, and using them in part to repay external debt rather than raise government consumption, has therefore likely been effective in reducing real appreciation.

\section{In addition, our results suggest that real appreciation is negatively associated with} foreign reserves accumulation. In particular, a one percent increase in NIR is associated with a reduction in the level of the real exchange rate by 0.18 percent in our baseline cointegrating equation. The other two estimated cointegrating equations give slightly lower estimates, but the estimates are statistically significant in all cases. This seems to suggest that the Central Bank is, to a limited extent, able to limit real appreciation pressures by buying up foreign exchange, thus increasing its foreign exchange reserves. However, the long-run effect of foreign exchange interventions on the real exchange rate should theoretically be zero, because unsterilized foreign exchange interventions should lead to inflation that eventually, as prices fully adjust, will offset the negative short-run effect on the real exchange rate. ${ }^{28}$ Since our sample period covers less than ten years, it may simply be too short for detecting this long-run money neutrality. An alternative explanation for the negative coefficient on net

\footnotetext{
${ }^{26}$ Sosunov and Zamulin (2006a) find that the oil price increase alone cannot explain the observed appreciation during the period 1999-2005, unless the increase is assumed to be permanent or Russian households are considered to be current income consumers. They suggest that another main determinant of real appreciation is the growth in oil export volumes. However, they do not control for other important determinants of the real exchange rate, such as the productivity differential and government consumption.

${ }^{27}$ To the extent that government spending will eventually have to be financed through higher taxes, this would offset the effect on real appreciation via a decline in disposable income and in the private demand for nontradables. However, as Edwards (1989) has argued, the first effect is likely to dominate the second effect, as long as governments have a higher propensity than taxpayers to consume nontradables. This is also generally confirmed by empirical studies (e.g., Froot and Rogoff, 1991;. Égert, Halpern, and MacDonald 2004, Table 5).

${ }^{28}$ Nevertheless, the long-run pass-through from nominal exchange rate to CPI has been typically estimated at around 0.5 for Russia (see, Oomes and Ohnsorge, 2005, and cited references). Using a different methodology, Sosunov and Zamulin (2006b) do find that reserves accumulation by the Central Bank of Russia has contributed somewhat to limiting long-run real exchange rate appreciation. However, it is possible that this small passthrough results from the fact that the Russian economy was probably operating well below potential until recently (Oomes and Dynnikova, 2006).
} 
international reserves is that increased government savings through the oil stabilization fund rose in tandem with international reserves, and these helped to contain inflationary pressures.

\section{Consistent with the Balassa-Samuelson hypothesis, we also find that real appreciation in Russia has been proportional to productivity differential growth. According to this} hypothesis, the real exchange rate will appreciate if (1) productivity growth in the tradables sector exceeds that in the nontradables sector (leading to an increase in the relative price of Russian nontradables, implying a rise in the overall price level); and (2) relative productivity growth (in the tradables sector relative to the nontradables sector) exceeds that in trade partner countries (this appears to have been the case for Russia since 1999). If both conditions hold, then the inflation differential is positive and the real exchange rate appreciates. Because of the absence of sufficiently long monthly time series for output and employment in nontradables sectors, we proxy the relative productivity differential by the productivity differential in the tradables (manufacturing) sector between Russia and its trade partners, as is common practice. Our coefficient estimates for the productivity differential are not significantly different from one, suggesting that a one percent increase in the productivity differential leads to approximately one percent real appreciation. This is consistent with the fact that the real exchange rate is roughly proportional to the productivity differential (last panel in Figure 3). Similar results have been found for Russia and for other transition economies. $^{29}$

Finally, our estimates suggest that corruption may reduce real appreciation pressures, but this result is not statistically significant. The estimated long-run elasticity is -0.53 in equation (3), but the standard error is 0.36 , that is, not significantly different from zero. This is probably the result of problems inherent in measuring corruption. Our proxy, the Transparency International Corruption Perceptions Index (CPI), is based on annual data and is generally considered more useful for cross-country studies than for time series analyses. ${ }^{30}$ Nevertheless, it seems intuitive that the effect should be negative, because a corrupt investment climate is likely to lead to capital outflows, and therefore may give rise to exchange rate depreciation (e.g., Wei and $\mathrm{Wu}, 2001$ ). Interestingly, a negative effect of corruption on the real exchange rate would imply that rent seeking behavior induced by higher oil prices may, to some extent, offset the Dutch Disease effects.

\footnotetext{
${ }^{29}$ For Russia, Spatafora and Stavrev (2003) find a long-run elasticity of 1.3 for relative productivity, with a standard error of 0.46. Similar results for other transition economies are reported in, e.g., Krajnyák and Zettelmeyer (1998), Égert (2002), Égert and others (2004), and Oomes (2005). Égert (2005) also finds that productivity growth has contributed to real exchange rate appreciation in a panel of countries, including Russia and Ukraine.

${ }^{30}$ The Transparency International Corruption Perceptions Index (CPI) compiles the corruption surveys and expert assessments available for each given country and pools them into a single measure of corruption, assigning the same weight to each source. However, the observations are generally not considered comparable over time, because the number of underlying sources changes every year (i.e., the sample is not balanced), and there have been frequent methodological improvements.
} 
Figure 3. Russia: Real Effective Exchange Rate and Its Determinants, 1995-2005
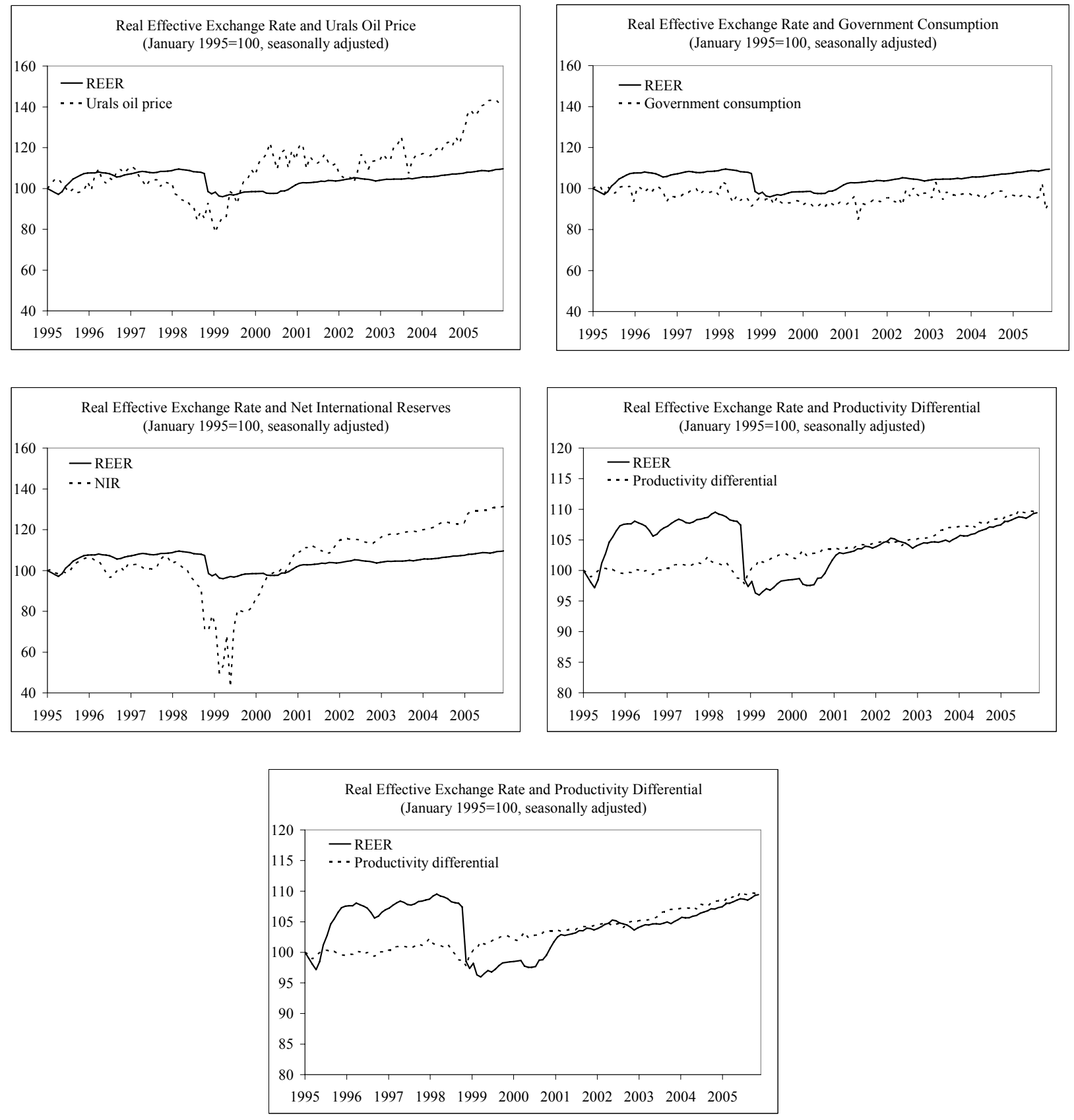
We find no evidence that the real exchange rate has been overvalued (above the estimated long run equilibrium level) in recent years. Figure 4 plots the difference between actual real exchange rate and the estimated long-run "equilibrium" level. Interpreting these deviations as a measure of misalignment, the results suggest that the real exchange rate was overvalued from mid-1997 until the August 1998 crisis, after which it remained undervalued until the end of 2000. There was another brief period of overvaluation from the end of 2000 until early 2002, but since that time, the real exchange rate appears to have been roughly in equilibrium, if not slightly undervalued.

Figure 4. Russia: Estimated Real Exchange Rate Misalignment, 1997-2005

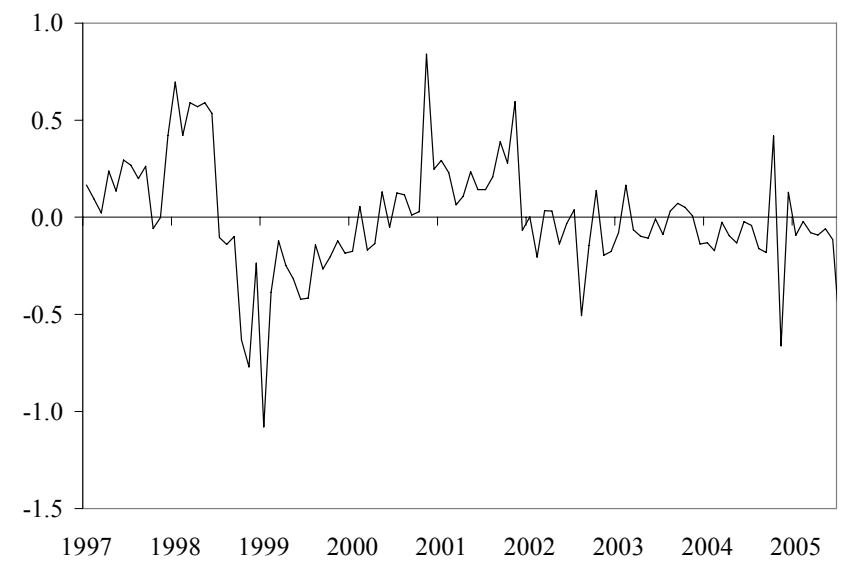

There are several reasons for this finding. The most important reason is probably Russia's prudent policy of saving part of the windfall revenues in a Stabilization Fund and using part of the revenues for repayment of foreign debt. A second reason is that the current account deteriorated due to faster import growth and slower export growth, thus lowering the pressure on the exchange rate. Finally, oil production growth itself slowed, implying lower windfall revenues than otherwise would have been expected.

\section{B. Manufacturing Sector Decline and Service Sector Growth}

In order to test for the other two symptoms of Dutch Disease (namely a slowdown in manufacturing growth and an increase in service sector growth) we use sector-level data to compare growth rates across Russian sectors for output, employment, real wages, and unit labor costs. Our sectoral data are based on the Russian Federal State Statistics Service's industrial classification system, which was used until December 2004. ${ }^{31}$ Using this classification system, we define Russia's resource sector as the "fuel" sector, which consists of oil extraction, oil processing, gas, and coal. ${ }^{32} \mathrm{We}$ define "manufacturing"

\footnotetext{
${ }^{31}$ The Russian Federal State Statistics Service ("Rosstat") has been using a new industrial classification scheme since January 2005, which is not comparable with the old industrial classification.

${ }^{32}$ To the extent that there may be some technological spillovers from oil refineries, the negative effects from Dutch Disease could be reduced by increasing the share of the refined oil exports.
} 
to consist of all industrial sectors excluding the fuel sector, which results in nine sectors: electricity, ferrous metals, non-ferrous metals, chemical and petrochemical, machinery, forestry and woodworking, light industry, and food. Finally, we define the "services" sector to consist of construction, communication, transportation, and trade.

\section{At first sight, there is no evidence of "absolute de-industrialization" (negative manufacturing growth). As the upper-left panel of Figure 5 shows, manufacturing output growth was negative only in 1998, following substantial depreciation of the ruble (and a large drop in oil prices), but has subsequently been positive. There is thus no evidence of de- industrialization in an absolute sense, which would imply negative manufacturing growth. While there is evidence of negative manufacturing employment growth between 2000 and 2004 , this is probably the result of an increase in manufacturing sector productivity or in capacity utilization (Oomes and Dynnikova, 2006). For similar reasons, employment in the fuel sector also declined in every year except in 2001 and 2003.}

However, in the presence of other growth determinants, it may be more appropriate to test for "relative de-industrialization." The absence of "absolute de-industrialization" does not necessarily imply that the data are inconsistent with the Dutch Disease model, because this model predicts that, all else equal, an increase in oil prices leads to a fall in manufacturing output. Nevertheless, there may have been changes in other variables that, at the same time, led to an offsetting increase in manufacturing output (for example, technological improvements, and the fall in foreign demand for Russian products following the significant exchange rate devaluation in 1998). To the extent these other variables equally affected all sectors, the Dutch Disease model would imply that we should expect "relative de-industrialization," i.e., slower growth in the manufacturing sector than in other sectors.

The data are consistent with this weaker version of the Dutch Disease hypothesis. As Figure 5 shows, the manufacturing sector has grown at a consistently slower rate than other sectors since 2001, implying a fall in the share of the manufacturing sector in total output. ${ }^{33}$ Similarly, the growth in services outpaced not only that for manufacturing but, since 2002, even that of the fuel sector, implying an increase in the relative size of the service sector. Moreover, the upper-right panel of Figure 5 shows that employment growth in the service sector has been positive since 2000 and exceeded employment growth in the other sectors in 2002 and 2004. This increase in both absolute and relative size of the service sector suggests that in Russia the spending effect has been more important than the resource movement effect. $^{34}$

\footnotetext{
${ }^{33}$ Sachs and Warner (2001) study de-industrialization by testing the relationship between resource abundance and the contribution of manufacturing export growth to overall GDP growth (which they find to be strongly negative). However, in our view, this would not be a good test for Russia because a significant share of manufacturing output is used for domestic consumption (import substitution) rather than for exports.

${ }^{34}$ Westin (2004) finds a similar result
} 
Figure 5. Russia: Sectoral Economic Indicators, 1997-2004
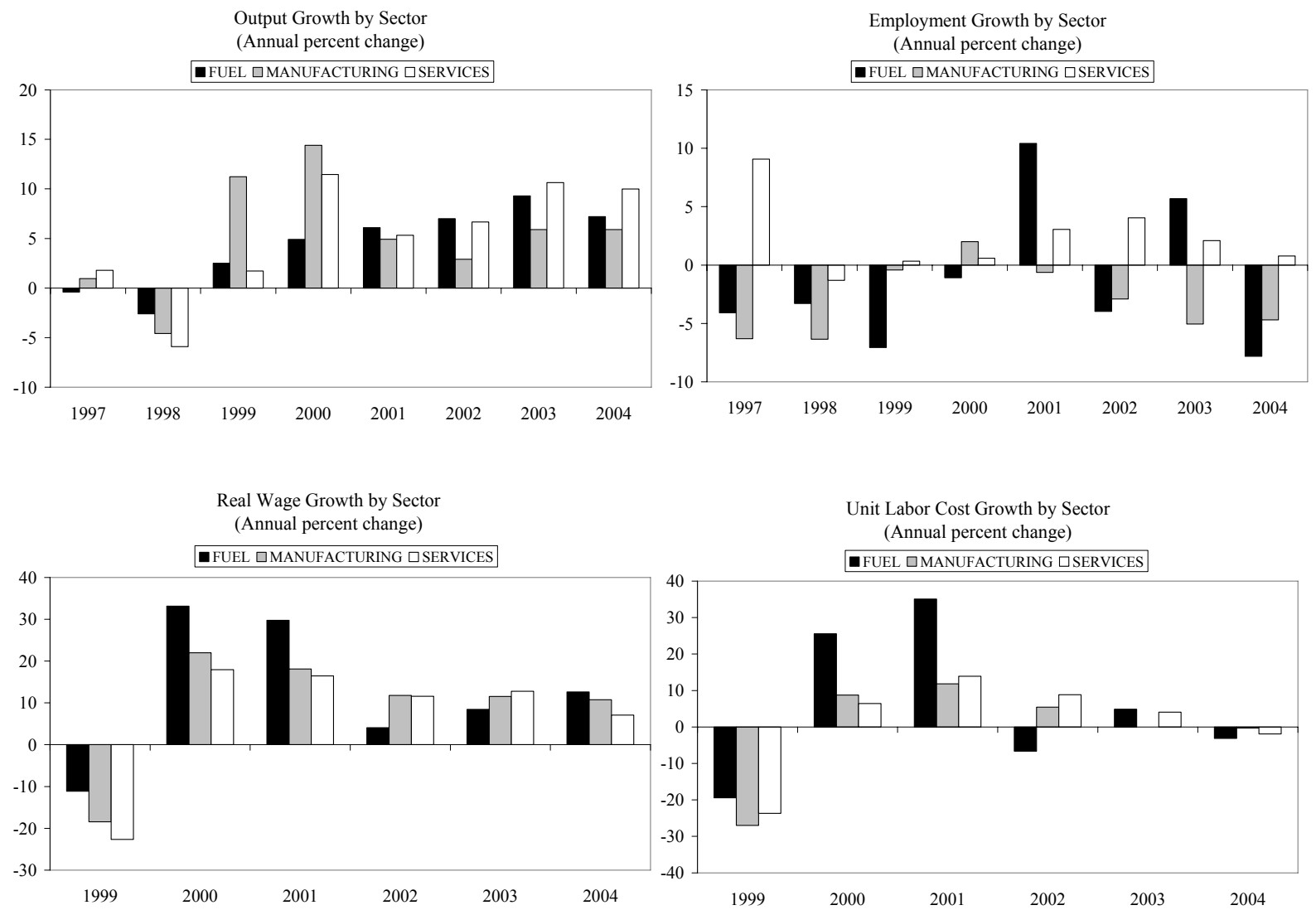

Figure 6 breaks down manufacturing growth by subsector, and shows that the slowdown in manufacturing growth occurred more or less across the board. Comparing 1997-2000 (low oil prices) with 2001-04 (high oil prices), we find that only the fuel sector, food sector, and electricity sector experienced actual increases in output growth. ${ }^{35}$ All other manufacturing sectors experienced substantially slower growth in 2001-04, when oil prices were high, with the light sector actually experiencing a decline. ${ }^{36}$ Data for 2004 and 2005, based on the new industrial classification system (albeit not comparable with the old system) suggest that manufacturing output growth picked up somewhat in the second half of 2005, but remained below the pace of 2004.

\footnotetext{
${ }^{35}$ A detailed sectoral study by the OECD (2004) suggests that the relatively high productivity growth rates observed in the Russian food sector may have been driven by FDI inflows (e.g., in tobacco and brewing companies). See also Ahrend (2004).

${ }^{36}$ This is consistent with the finding of Plekhanov (2005) that ruble appreciation had the strongest impact on light industry in 2004 , as measured by industrial real exchange rate indices.
} 
Figure 6. Russia: Industrial Growth Rates by Sector (Average annual percent change, at constant prices)

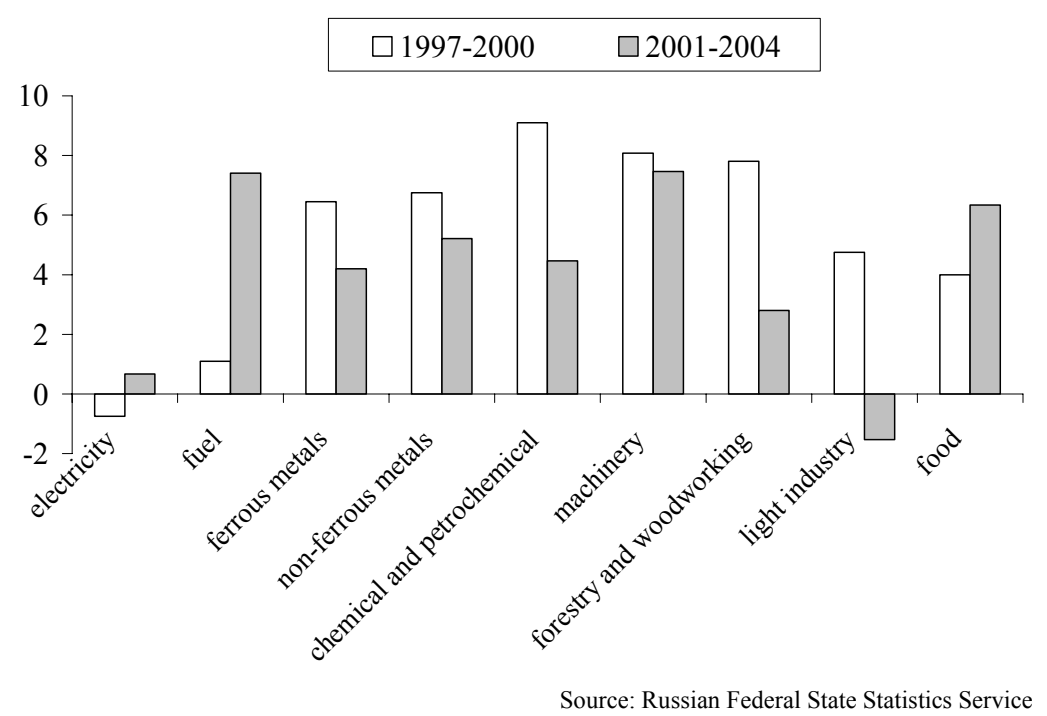

However, even "relative de-industrialization" (decline of the manufacturing sector relative to the service sector) cannot necessarily be regarded as evidence of Dutch Disease, because it may have occurred for other, transition-related reasons. Unlike other resource-based economies in Europe and Africa, Russia's economy has undergone significant structural changes during the post-Soviet transition period. In particular, many manufacturing firms, which had received significant state support during Soviet times, proved uncompetitive and disappeared when they were opened up to capitalist competition. At the same time, the service sector had remained undeveloped during Soviet times and only started growing during the transition period. To the extent that this "transition effect" had not yet been undone by 2000 , it could partly explain the relative de-industrialization seen in the data.

It is difficult to determine whether manufacturing growth has in fact slowed as a result of high oil prices in 2005, because many non-oil manufacturing sectors are indirectly dependent on oil prices (Table 3). We estimate the effect of higher oil prices on five non-oil manufacturing sectors (machinery, chemical and petrochemical, forestry and woodworking, light industry, and food), ${ }^{37}$ controlling for changes in foreign demand. We also estimate the overall effect on a "manufacturing index" (excluding oil), which we construct based on monthly industrial production growth rates for each subsector, using variable weights, similar

\footnotetext{
${ }^{37}$ According to a Russian survey, conducted by the Institute for Complex Strategic Studies in Moscow (Plekhanov, 2005), these sectors were most strongly impacted by high oil prices.
} 
Table 3. Effect of Oil Prices on Manufacturing Output: Estimated Cointegrating Vectors

\begin{tabular}{|c|c|c|c|c|c|c|}
\hline $\begin{array}{l}\text { Dependent variable } \\
\text { Ln(sector) }\end{array}$ & machinery & chemicals & forestry & light & food & manuf. index \\
\hline First observation & $1997: 05$ & 1997:01 & 1997:01 & 1997:01 & 1997:01 & 1997:01 \\
\hline Last observation & 2005:11 & 2005:11 & $2005: 11$ & $2005: 11$ & $2005: 11$ & 2005:11 \\
\hline Number of observations & 107 & 107 & 107 & 107 & 107 & 107 \\
\hline $\begin{array}{l}\text { Ln (oil price) } \\
\text { standard error } \\
\text { t-statistics }\end{array}$ & $\begin{array}{l}\mathbf{2 . 2 3} \\
(0.88) \\
{[2.55]}\end{array}$ & $\begin{array}{l}0.16 \\
(0.11) \\
{[1.42]}\end{array}$ & $\begin{array}{c}\mathbf{0 . 3 1} \\
(0.11) \\
{[-2.87]}\end{array}$ & $\begin{array}{c}-\mathbf{0 . 3 2} \\
(0.11) \\
{[-2.74]}\end{array}$ & $\begin{array}{l}\mathbf{0 . 3 1} \\
(0.11) \\
{[2.72]}\end{array}$ & $\begin{array}{r}-0.36 \\
(0.20) \\
{[1.82]}\end{array}$ \\
\hline $\begin{array}{c}\text { Ln (EU_imp) } \\
\text { standard error } \\
\text { t-statistics }\end{array}$ & $\begin{array}{l}\mathbf{- 1 . 6 6} \\
(0.65) \\
{[2.55]}\end{array}$ & $\begin{array}{l}\mathbf{0 . 2 3} \\
(0.08) \\
{[2.83]}\end{array}$ & $\begin{array}{c}0.13 \\
(0.08) \\
{[1.55]}\end{array}$ & $\begin{array}{c}\mathbf{0 . 5 2} \\
(0.09) \\
{[5.84]}\end{array}$ & $\begin{array}{c}0.06 \\
(0.09) \\
{[-0.75]}\end{array}$ & \\
\hline Trend & & & & & & 0.01 \\
\hline LM test for serial correlation & 0.92 & 0.91 & 0.40 & 0.54 & 0.51 & 0.21 \\
\hline Jarque-Bera normality test & 0.11 & 0.19 & 0.11 & 0.06 & 0.11 & 0.00 \\
\hline Heteroskedasticity test & 0.01 & 0.05 & 0.04 & 0.01 & 0.04 & 0.01 \\
\hline $\mathrm{AIC}$ & -1.68 & -4.33 & -3.81 & -3.24 & -4.26 & -3.29 \\
\hline $\mathrm{SC}$ & -1.28 & -3.92 & -3.41 & -2.84 & -3.86 & -2.99 \\
\hline Log likelihood & 105 & 247 & 219 & 189 & 243 & 199 \\
\hline
\end{tabular}

Note: In Eq $(1,2,3,4,5)$ the dependent variable is an individual index of each of the five main industrial sectors. In Eq (6) the dependent variable is the log of the total weighted index of industrial production, including five main industrial sectors. All regressions include four lags and a constant or trend.

to Westin (2004). ${ }^{38}$ The results, reported in Table 3, are mixed. On the one hand, we find that light industry production slowed down (its coefficient is negative) as a result of higher oil prices, which is what we would expect. On the other hand, we find that higher oil prices had a positive and significant impact on the other manufacturing sectors, in particular, machinery, forestry, and food, even after controlling for foreign demand (denoted by "EU_imp" in Table 3). ${ }^{39}$ This positive effect can perhaps be explained by the fact that even the non-oil manufacturing sector is to an extent dependent on oil prices, implying an indirect effect of higher oil prices on certain sectors (e.g., production of railway cars boomed in response to higher oil prices and the need to transport more oil by rail, given pipeline bottlenecks.)

\footnotetext{
${ }^{38}$ The sectors are weighted by relative shares in industrial production and in real GDP. As mentioned above, the new industrial classification scheme used by Rosstat since January 2005 is not comparable with the old industrial classification, which is why we treat 2005 separately.

${ }^{39}$ Foreign demand is proxied by EU-25 imports from Russia. A positive coefficient means that an increase in foreign demand results in an increase in production.
} 
After controlling for the "transition effect," we do not find a significantly negative effect of oil prices on manufacturing growth. The restructuring of the Russian economy in the early1990s was directed toward faster growth and significant structural changes in all sectors of the economy. In order to correct for this "transition effect," it is necessary to show that higher oil prices led to faster manufacturing growth than would have occurred otherwise. To control for this effect, we include a trend variable, the parametric value of which can be interpreted as representing the long-run change in the dependent variable, assuming that oil prices and other variables are fixed. ${ }^{40}$ Equation (6) in Table 3 shows the estimated cointegrating vector including this trend and the overall "manufacturing index" as a dependent variable. These estimates suggests that the overall impact of oil prices on total manufacturing output up to the end of 2005 was in fact negative, as predicted by the Dutch Disease hypothesis, albeit not significantly so.

\section{Wage Growth}

We find clear evidence of rapid real wage growth in all sectors since 2000, which is consistent with both resource movement and spending effects. As the lower left panel of Figure 5 shows, the sharpest increase in real wages occurred initially in the fuel sector, probably due to soaring oil prices in 2000 , which could have given rise to either a resource movement or spending effect, or both. However, wage growth in the other sectors was also rapid and quickly caught up with fuel sector wage growth, as predicted by the Dutch Disease hypothesis. In fact, in 2002 and 2003, wages in manufacturing and services rose even faster than in the fuel sector. In general, however, real wage growth did not differ much between sectors between 2002 and 2004.

However, just as with the other symptoms, the rapid real wage growth since 2000 may well be explained by factors other than Dutch Disease. One such factor is the 1998 crisis, which resulted in a significant drop in real wages in 1999, implying that part of the real wage growth was simply a rebound from the crisis. Another possible factor is the so-called deshadowization of wages, meaning that previously unrecorded wages have gradually started to appear in the official statistics, implying an increase in reported real wage growth but not in actual real wage growth. A final factor is that the significant real wage growth during the last few years appears to have been largely explained by productivity growth. According to our calculations (based on several assumptions, with missing data, and so to be interpreted with caution), productivity-adjusted wage growth (i.e., unit labor cost growth) was close to zero in all sectors between 2002 and 2004, as illustrated in the bottom right panel of Figure $5 .{ }^{41}$

\footnotetext{
${ }^{40}$ Rautava (2004) finds that a number of diagnostic tests support the inclusion of a trend in a long-run cointegrating vector in which the long-run level of GDP depends positively on the oil price and negatively on the real exchange rate, estimated for the period 1995-2002. The coefficient estimate for the trend suggests that the underlying annual long-run growth rate of Russian GDP is about 3 percent, which he interprets as "capturing the impact of Russia's modernization process" (p. 322).

${ }^{41}$ Unit labor costs, or productivity-adjusted wages, are defined as $\mathrm{W} /(\mathrm{Y} / \mathrm{L})=\mathrm{WL} / \mathrm{Y}$, where $\mathrm{W}$ denotes the real wage, $\mathrm{Y}$ output, and L employment, so that $\mathrm{Y} / \mathrm{L}$ equals productivity.
} 
After controlling for the "transition effect," we do not find a significantly negative effect of oil prices on manufacturing growth. The restructuring of the Russian economy in the early1990s was directed toward faster growth and significant structural changes in all sectors of the economy. In order to correct for this "transition effect," it is necessary to show that higher oil prices led to faster manufacturing growth than would have occurred otherwise. To control for this effect, we include a trend variable, the parametric value of which can be interpreted as representing the long-run change in the dependent variable, assuming that oil prices and other variables are fixed. ${ }^{42}$ Equation (6) in Table 3 shows the estimated.

\section{CONCLUSION}

This paper studied whether recent economic developments in Russia have been symptomatic of Dutch Disease. The four main symptoms we tested for include (1) an appreciation of the real exchange rate; (2) a slowdown in manufacturing growth (deindustrialization); (3) an increase in service sector growth; and (4) an increase in wage growth.

Regarding the first symptom, there is evidence that oil prices have strengthened the real ruble exchange rate. Based on cointegration techniques, we find that a one percent increase in the Urals oil price leads to a 0.50 percent appreciation of the real exchange rate, although the estimated elasticity varies for other specifications. These estimates were derived while controlling for other real exchange rate determinants. We find that the level of the real exchange rate is positively correlated with Russia's productivity differential and government consumption, and is negatively correlated with net international reserves and corruption.

However, we do not find evidence that the real exchange rate has been above the estimated equilibrium level. While there was a brief period of overvaluation in 2001, we estimate that the real exchange rate has been roughly in equilibrium, or possibly even undervalued, since 2002. While there may thus be evidence of Dutch Disease (in the sense that higher oil prices have given rise to real appreciation), it is not clear that this real appreciation has been responsible for the observed slowdown in manufacturing growth. In order to establish this connection, further micro-level research would be needed to determine the effects of real appreciation on separate sectors or individual firms.

We do find evidence that Russia exhibited the other three symptoms. In particular, our sectoral data show that the manufacturing sector has grown more slowly than other sectors since 2001, while manufacturing employment growth has fallen. We also find evidence that the share of the service sector has increased, suggesting that the spending effect has been more important in Russia than the resource movement effect. Moreover, we find clear

\footnotetext{
${ }^{42}$ Rautava (2004) finds that a number of diagnostic tests support the inclusion of a trend in a long-run cointegrating vector in which the long-run level of GDP depends positively on the oil price and negatively on the real exchange rate, estimated for the period 1995-2002. The coefficient estimate for the trend suggests that the underlying annual long-run growth rate of Russian GDP is about 3 percent, which he interprets as "capturing the impact of Russia's modernization process" (p. 322).
} 
evidence of high real wage growth in all sectors since 2000, which is consistent with both the resource movement and the spending effect.

However, it is difficult to conclude that the observed symptoms are indeed the result of Dutch Disease, because they can be explained by other factors as well. In particular, an increase in the relative size of the service sector may be a natural "transition" phenomenon, given that the manufacturing sector had received significant state support during Soviet times, while the service sector remained artificially undeveloped. Moreover, deindustrialization has been a natural phenomenon even in the United States and other advanced industrial countries that are not necessarily resource-rich, simply because, as households become richer, demand naturally tends to shift away from goods toward services. Similarly, the rapid observed wage growth in Russia since 2000 may well be the result of the de-shadowization of wages, rapid productivity growth, and a rebound from the 1998 crisis.

If the slowdown in the Russian manufacturing sector is, indeed, the result of excessive real appreciation, then limiting real appreciation may be important to reduce the effects of Dutch Disease. Trading off nominal appreciation for inflation, or vice versa, does not help to improve competitiveness, as both inflation and nominal appreciation lead to higher prices for Russian goods abroad. This reduces the profit margins of Russian exporters (manufacturers and oil exporters alike), who need to convert foreign currency into rubles in order to pay taxes and wages. Our estimates suggest that foreign exchange interventions (reflected in reserve accumulation) may help somewhat to reduce real appreciation, but only to a limited extent. More effective ways to reduce real appreciation pressures would be to reduce government consumption as a share of GDP and to raise tax revenues. ${ }^{43}$

We have several suggestions for further research. First, it may be important to correct for "initial undervaluation", for example, by estimation of the core-CPI based REER, e.g., as in Oomes (2005). Second, it might be interesting to test for an asymmetric effect of the oil prices on the real exchange rate. For example, Merlevede et al. (2004) and Rautava (2004) find that the negative effect of a drop in the oil price is stronger than the positive effect of an increase in the oil price. Third, it may be necessary to include additional determinants of real appreciation. For example, Sosunov and Zamulin (2006a) suggest that another main determinant is the growth of oil export volumes.

We conclude that, while Russia does appear to have all of the symptoms, the diagnosis of Dutch Disease remains to be confirmed. Although we find evidence of real appreciation, a declining manufacturing sector, an expanding service sector, and rapid real wage growth, more research is needed to determine that these symptoms are not caused by other factors. Nevertheless, the risk of Dutch Disease exists and warrants close monitoring.

\footnotetext{
${ }^{43}$ The policy agenda for 2007 includes legislative amendments for better collection of value added and corporate profit taxes, while allowing tax breaks to oil firms who develop unexploited deposits.
} 


\title{
APPENDIX. DesCRIPTIVE STATISTICS
}

\author{
Table A1. Data Description and Sources
}

Data Sources and Description

\begin{tabular}{|c|c|c|c|}
\hline VARIABLE & SOURCE & FREQUENCY & DESCRIPTION \\
\hline Real effective exchange rate & IFS & Monthly & CPI-based index, 1995=100. \\
\hline Oil price & Bloomberg & Monthly & Urals crude oil price per barrel. \\
\hline Government consumption & IMF, IFS & $\begin{array}{l}\text { Monthly } \\
\text { Quatrely }\end{array}$ & $\begin{array}{l}\text { General government non-interest } \\
\text { expenditure, in percent of GDP } \\
\text { (interpolated). }\end{array}$ \\
\hline Productivity differential & $\begin{array}{l}\text { Rosstat, Eurostat, U.S. } \\
\text { National Census bureau }\end{array}$ & Monthly & $\begin{array}{l}\text { The ratio of Russian labor productivity to the } \\
\text { equally weighted Euro area and U.S. labor } \\
\text { productivity (where labor productivity is } \\
\text { measured as industrial output per worker). }\end{array}$ \\
\hline Net international reserves & IFS & Monthly & $\begin{array}{l}\text { Gross international reserves (including gold) } \\
\text { minus liabilities to IMF. }\end{array}$ \\
\hline Industrial production & Rosstat & Monthly & $\begin{array}{l}\text { Weighted monthly industrial production } \\
\text { index until end-2004 incl. five industries - } \\
\text { machinery, chemicals, forestry, light and } \\
\text { food industries and "manufacturing" index } \\
\text { for } 2005\end{array}$ \\
\hline Foreign demand & Eurostat & Monthly & $\begin{array}{l}\text { Proxied by the total EU-25 imports from } \\
\text { Russia }\end{array}$ \\
\hline Corruption & Transparency International & Annual & Survey-based index (interpolated). \\
\hline
\end{tabular}

Table A2. Correlation Matrix

\begin{tabular}{lcrrrrr}
\hline & $\begin{array}{c}\text { Real effective } \\
\text { exchange rate }\end{array}$ & Oil price & $\begin{array}{r}\text { Government } \\
\text { consumption }\end{array}$ & $\begin{array}{r}\text { Productivity } \\
\text { differential }\end{array}$ & $\begin{array}{r}\text { Net } \\
\text { international } \\
\text { reserves }\end{array}$ & $\begin{array}{r}\text { Corruption } \\
\text { index }\end{array}$ \\
\hline Real effective exchange rate & 1.00 & 0.14 & 0.44 & 0.13 & 0.56 & 0.32 \\
Oil price & 0.14 & 1.00 & -0.09 & 0.77 & 0.74 & 0.28 \\
Government consumption & 0.44 & -0.09 & 1.00 & -0.13 & 0.21 & 0.42 \\
Productivity differential & 0.13 & 0.77 & -0.13 & 1.00 & 0.68 & 0.42 \\
Net international reserves & 0.56 & 0.74 & 0.21 & 0.68 & 1.00 & 0.41 \\
Corruption index & 0.32 & 0.28 & 0.42 & 0.42 & 0.41 & 1.00 \\
\hline
\end{tabular}


Table A3. Augmented Dickey-Fuller (ADF) Unit Root Tests

\begin{tabular}{|c|c|c|c|c|c|}
\hline \multicolumn{3}{|c|}{$\begin{array}{l}\text { ADF tests for unit root in levels } \\
\text { 1997:M1-2005:M12 }\end{array}$} & \multicolumn{3}{|c|}{$\begin{array}{l}\text { ADF tests for unit root in differences } \\
\text { 1997:M1-2005:M12 }\end{array}$} \\
\hline \multicolumn{3}{|c|}{$\ln ($ REER) } & \multicolumn{3}{|c|}{$\Delta \ln ($ REER) } \\
\hline lag & t-adf & beta & lag & t-adf & beta \\
\hline 4 & -2.123 & -0.050 & 4 & $-3.899 * *$ & -0.678 \\
\hline 3 & -2.034 & -0.047 & 3 & $-4.090 * *$ & -0.653 \\
\hline 2 & -1.539 & -0.039 & 2 & $-4.535 * *$ & -0.655 \\
\hline 1 & -1.583 & -0.036 & 1 & $-6.994 * *$ & -0.854 \\
\hline 0 & -1.203 & -0.028 & 0 & $-8.507 * *$ & -0.799 \\
\hline \multicolumn{3}{|c|}{$\ln$ (oil prices) } & \multicolumn{3}{|c|}{$\Delta \ln$ (oil prices) } \\
\hline 4 & -2.207 & -0.112 & 4 & $-4.852 * *$ & -1.483 \\
\hline 3 & -2.169 & -0.106 & 3 & $-6.187 * *$ & -1.598 \\
\hline 2 & -2.002 & -0.095 & 2 & $-7.091 * *$ & -1.489 \\
\hline 1 & -2.411 & -0.112 & 1 & $-10.136 * *$ & -1.501 \\
\hline 0 & -2.781 & -0.125 & 0 & $-13.043 * *$ & -1.222 \\
\hline \multicolumn{3}{|c|}{ ln (productivity differential) } & \multicolumn{3}{|c|}{$\Delta \ln$ (productivity differential) } \\
\hline 4 & -2.048 & -0.234 & 4 & $-5.364 * *$ & -1.279 \\
\hline 3 & -2.231 & -0.247 & 3 & $-5.440 * *$ & -1.136 \\
\hline 2 & -2.669 & -0.286 & 2 & $-5.423 * *$ & -0.998 \\
\hline 1 & -3.805 & -0.394 & 1 & $-7.635 * *$ & -1.123 \\
\hline 0 & $-2,896 *$ & -0.144 & 0 & $-12.069 * *$ & -1.146 \\
\hline \multicolumn{3}{|c|}{ ln (government consumption) } & \multicolumn{3}{|c|}{$\Delta \ln$ (government consumption) } \\
\hline 4 & -2.130 & 0.019 & 4 & $-7.280 * *$ & -3.432 \\
\hline 3 & -2.320 & 0.200 & 3 & $-7.525 * *$ & -2.858 \\
\hline 2 & -2.689 & 0.224 & 2 & $-9.504 * *$ & -2.598 \\
\hline 1 & $-3,633 *$ & 0.296 & 1 & $-12.952 * *$ & -2.168 \\
\hline 0 & $-7,204 * *$ & 0.646 & 0 & $-19.901 * *$ & -1.571 \\
\hline \multicolumn{3}{|c|}{ ln (net international reserves) } & \multicolumn{3}{|c|}{$\Delta \ln$ (net international reserves) } \\
\hline lag & t-adf & beta & lag & t-adf & beta \\
\hline 4 & $-2,616$ & -0.106 & 4 & $-3.940 *$ & -0.984 \\
\hline 3 & $-2,222$ & -0.089 & 3 & $-4.066 * *$ & -0.934 \\
\hline 2 & $-1,775$ & -0.072 & 2 & $-5.610 * *$ & -1.135 \\
\hline 1 & $-2,085$ & -0.084 & 1 & $-9.977 * *$ & -1.479 \\
\hline 0 & -2.454 & -0.097 & 0 & $-12.993 * *$ & -1.220 \\
\hline \multicolumn{6}{|c|}{$\begin{array}{l}{ }^{1} \text { The regression includes a constant and a trend. The critical values of the Augmented Dickey-Fuller } \\
\text { (ADF) t-statistics are based on MacKinno (1996) one sided p-values. The null hypothesis is that of a unit } \\
\text { root in levels, i.e., rejection of the null means that the variable is stationary in levels. The symbols * and } \\
\text { ** denote significance at the } 5 \text { percent and } 1 \text { percent level, respectively. }\end{array}$} \\
\hline \multicolumn{6}{|c|}{$\begin{array}{l}{ }^{2} \text { The regression includes a constant. The critical values of the Augmented Dickey-Fuller (ADF) t- } \\
\text { statistics are based on MacKinno (1996) one sided p-values. The null hypothesis is that of a unit root in } \\
\text { differences, i.e., rejection of the null means that the variable is stationary in differences. The symbols * } \\
\text { and } * * \text { denote significance at the } 5 \text { percent and } 1 \text { percent level, respectively. }\end{array}$} \\
\hline
\end{tabular}


Table A4. Johansen Cointegration Tests

\begin{tabular}{|c|c|c|c|}
\hline \multicolumn{4}{|c|}{ (1) } \\
\hline$\lambda$ trace & prob. & $\lambda \max$ & prob. \\
\hline 62.04 & {$[0.001] * *$} & 49.10 & {$[0.000] * *$} \\
\hline 12.34 & {$[0.894]$} & 9.88 & {$[0.756]$} \\
\hline 3.06 & {$[0.964]$} & 2.68 & {$[0.966]$} \\
\hline 0.38 & {$[0.538]$} & 0.38 & {$[0.538]$} \\
\hline \multicolumn{4}{|c|}{ (2) } \\
\hline$\lambda$ trace & prob. & $\lambda \max$ & prob. \\
\hline 94.33 & {$[0.000] * *$} & 54.73 & {$[0.000] * *$} \\
\hline 39.59 & {$[0.237]$} & 24.84 & {$[0.108]$} \\
\hline 14.76 & {$[0.795]$} & 9.68 & {$[0.775]$} \\
\hline 5.08 & {$[0.780]$} & 4.62 & {$[0.788]$} \\
\hline \multicolumn{4}{|c|}{ (3) } \\
\hline$\lambda$ trace & prob. & $\lambda \max$ & prob. \\
\hline 127.95 & {$[0.000] * *$} & 40.08 & {$[0.000] * *$} \\
\hline 63.58 & {$[0.142]$} & 33.88 & {$[0.141]$} \\
\hline 33.75 & {$[0.516]$} & 27.58 & {$[0.263]$} \\
\hline 12.25 & [0.912] & 21.13 & [0.929] \\
\hline \multicolumn{4}{|c|}{$\begin{array}{l}\text { Notes: Estimations include four lags, a constant, and two } \\
\text { dummies for September and October } 1998 \text { to control for the } \\
\text { large real depreciation following the Russian financial } \\
\text { crisis in August } 1998 . \text { The symbols } * \text { and } * * \text { denote } \\
\text { significance at the } 5 \text { percent and } 1 \text { percent level, } \\
\text { respectively. }\end{array}$} \\
\hline
\end{tabular}




\section{REFERENCES}

Adam, Christopher S. and David L. Bevan, 2003, “Aid, Public Expenditure and Dutch Disease," Centre for the Study of African Economies Working Paper 2003-02 (Oxford: University of Oxford).

Ahrend, Rudiger, 2004, "Russian Industrial Restructuring: Trends in Productivity, Competitiveness and Comparative Advantage," ECO/WKP No. 31 (Paris: OECD). , 2006, "Russia's Post-Crisis Growth: Its Sources and Prospects for Continuation," Europa-Asia Studies, Vol. 58, No.1, pp. 1-24.

Aizenman, Joshua and Nancy Marion, 1999, "Volatility and Investment: Interpreting Evidence from Developing Countries," Economica, Vol. 66, pp. 157-79.

Andrienko, Yuri and Sergei Guriev, 2004, "Determinants of Interregional Labor Mobility in Russia: Evidence from Panel Data," Economics of Transition, Vol. 12, No. 1, pp. 127.

Buiter, Willem and Douglas D. Purvis, 1983, “Oil, Disinflation and Export Competitiveness: A Model of the 'Dutch Disease'," National Bureau of Economic Research Working Paper 592 (Cambridge, Mass: NBER).

Bulir, Ales and Timothy D. Lane, 2002, "Aid and Fiscal Management," IMF Working Paper 02/112 (Washington: International Monetary Fund).

Caballero, Ricardo J., 1991, "On the Sign of the Investment-Uncertainty Relationship," American Economic Review, Vol. 81, No. 1, pp. 279-88.

Collier, Paul and Anke Hoeffler, 2004, "Greed and Grievance in Civil War," Oxford Economic Papers, Vol. 56, No. 4, pp. 563-95.

Corden, W. Max, 1984, "Booming Sector and Dutch Disease Economics: Survey and Consolidation," Oxford Economic Papers, Vol. 36 (November), pp. 359-80.

Corden, W. Wax, and J. Peter Neary, 1982, "Booming Sector and De-Industrialisation in a Small Open Economy,” The Economic Journal, Vol. 92 (December), pp. 825-48.

De Gregorio, Jose and Holger Wolf, 1994, “Terms of Trade, Productivity, and the Real Exchange Rate," National Bureau of Economic Research Working Paper 4807 (Cambridge, Mass: NBER).

Desai, Padma, 2006, "Why is Russian GDP Growth Slowing?" American Economic Review Papers and Proceedings, Vol. 96, No. 2, pp. 342-7. 
Edwards, Sebastian, 1989, Real Exchange Rates, Devaluation, and Adjustment (Cambridge, Massachusetts: MIT Press).

Égert, Balazs, 2002, "Investigating the Balassa-Samuelson Hypothesis in the Transition: Do We Understand What We See? A Panel Study," Economics of Transition, Vol. 10, No. 2, pp. 273-309.

, 2005, "Equilibrium Exchange Rates in South Eastern Europe, Russia, Ukraine and Turkey: Healthy or (Dutch) Diseased?" Economic Systems, Vol. 29, No. 2, pp. $205-41$.

, 2006, "The Dutch Disease in Kazakhstan: An Empirical Investigation," Focus on European Economic Integration, No. 2/06, pp. 85-108. Available via the Internet: www.oenb.at/de/geldp_volksw/zentral_osteuropa/feei_fot/feei_2_2006.jsp\#tcm:14$\underline{49908}$

Égert, Balázs, László Halpern, and Ronald MacDonald, 2004, "Equilibrium Exchange Rates in Transition Economies: Taking Stock of the Issues," Centre for Economic Policy Research Discussion Paper No. 4809 (London: Centre for Economic Policy Research Discussion Paper). Available via the Internet: www.cepr.org/pubs/dps/DP4809.asp

Flug, Karnit, Antonio Spilimbergo, and Erik Wachtenheim, 1998, "Investment in Education: Do Economic Volatility and Credit Constraints Matter?" Journal of Development Economics, Vol. 55, No. 2, pp. 465-4.

Froot, Kenneth A. and Kenneth Rogoff, 1991, "The EMS, the EMU, and the Transition to a Common Currency," National Bureau of Economic Research Working Paper No. 3684 (Cambridge, Mass: NBER).

Gurvich, E. T., 2004, "A Macroeconomic Estimate of the Role of the Russian Oil-Gas Sector" (in Russian) [Макроэкономическая оценка роли российского нефтегазового сектора], Voprosy Ekonomiki, No. 10.

Gylfason, Thorvaldur, Tryggvi Herbertsen, and Gylfi Zoega, 1999, “A Mixed Blessing: Natural Resources and Economic Growth," Macroeconomic Dynamics Vol. 3, pp. $204-55$.

Gylfason, Thorvaldur, 2004, "Natural resources and Economic growth: from dependence to diversification," CEPR Discussion paper 4804.

Hausmann, Ricardo and Roberto Rigobon, 2003, "An alternative interpretation for the resource curse: theory and policy implications" in: Fiscal Policy Formulation and Implementation in Oil Producing Countries, ed. by Davis and others (Washington: International Monetary Fund). 
International Energy Agency, 2004, World Energy Outlook 2004 (Paris: International Energy Agency).

Agency). , 2005, World Energy Outlook 2005 (Paris: International Energy

Energy Agency). , 2006, "Monthly Oil Market Report” (Paris: International

International Monetary Fund, 2005, "Russian Federation: Statistical Appendix," IMF Country Report No. 05/378 (Washington: International Monetary Fund).

Isham, Jonathan, Lant Pritchett, Michael Woolcock, and Gwen Busby, 2005, “The Varieties of Rentier Experience: How Natural Resource Endowments Affect the Political Economy of Economic Growth," The World Bank Economic Review, Vol. 19, No. 2, pp.141-174.

Krajnyák, Kornelia and Jeronimo Zettelmeyer, 1998, "Competitiveness in Transition Economies-What Scope for Real Appreciation?" IMF Staff Papers, Vol. 45 No. 2, pp. 309-362.

Krugman, Paul, 1997, "The Narrow Moving Band, the Dutch Disease and the Competitive Consequences of Mrs. Thatcher," Journal of Development Economics, Vol. 27, pp. $41-55$.

Kutan, Ali M. and Michael Louis Wyzan, 2005, "Explaining the Real Exchange Rate in Kazakhstan, 1996-2003: Is Kazakhstan Vulnerable to the Dutch Disease?" Economic Systems, Vol. 29, No. 2, pp. 242-255.

Lane, Philip and Aaron Tornell, 1996, "Power, Growth, and the Voracity Effect," Journal of Economic Growth, Vol. 1, No. 2, pp. 213-41.

Latsis, O., 2005, "Dutch Disease Hits Russia," Moscow News, June 8-14. Available via the Internet: http://www.cdi.org/russia/johnson/9173-16.cfm

Leite, Carlos and Jens Weidmann, 1999, "Does Mother Nature Corrupt? Natural Resources, Corruption, and Economic Growth," IMF Working Paper 99/85 (Washington: International Monetary Fund).

Mauro, Paolo, 1995, “Corruption and Growth," Quarterly Journal of Economics, Vol. 90, pp. 681-712.

Merlevede, Bruno, Bas van Aarle, and Koen Schoors, 2004, "Russia from Bust to Boom: Oil, Politics or the Ruble?” William Davidson Institute Working Paper No. 722. 
Nkusu, Mwanza, 2004, "Aid and the Dutch Disease in Low-Income Countries: Informed Diagnoses for Prudent Prognoses,” IMF Working Paper 04/49, March (Washington: International Monetary Fund).

, 2005, "Terms of Trade and Economic Growth in the Former Soviet Union," in: Russian Federation: Selected Issues (Washington: International Monetary Fund).

OECD, 2004, Economic Surveys: Russian Federation (Paris: OECD).

Oomes, Nienke, 2005, "Maintaining Competitiveness under Equilibrium Real Appreciation: The Case of Slovakia," Economic Systems, Vol. 29, No. 2, pp. 187-204 (also published as IMF Working Paper No. 05/65).

Oomes, Nienke and Franziska Ohnsorge, 2005, "Money Demand and Inflation in Dollarized Economies: The Case of Russia," Journal of Comparative Economics, Vol. 33, No. 3, pp. 462-83 (also published as IMF Working Paper 05/144).

Oomes, Nienke and Oksanna Dynnikova, 2006, "The Utilization-Adjusted Output Gap: Is the Russian Economy Overheating?” IMF Working Paper No. 06/68 (Washington: International Monetary Fund)

OPEC, 2005, Organization of the Petroleum Exporting Countries, OPEC Bulletin, Vol. 11-12 (Vienna: OPEC).

Plekhanov, Dmitriy, 2005, “Отраслевые индексы реального эффективного курса рубля,” in Russian (Moscow: Institute for Complex Strategic Studies), Available via the Internet: http://www.icss.ac.ru/publish/analysis/index.html?newver=rus

Rajan, Raghuram G. and Arvind Subramanian, 2005, "What Undermines Aid's Impact on Growth?” IMF Working Paper 05/126(Washington: International Monetary Fund).

Ramey, Garey and Valerie A. Ramey, 1995, "Cross-Country Evidence on the Link Between Volatility and Growth," American Economic Review, Vol. 85, pp. 1138-51.

Rautava, Jouko, 2004, "The Role of the Oil Prices and the Real Exchange Rate in Russia's Economy-A Cointegration Approach," Journal of Comparative Economics, Vol. 32, No. 2, pp. 315-27.

Roland, Gérard, 2005, “The Russian Economy in the Year 2005," mimeo (Berkeley: University of California at Berkeley). Available via the Internet: http://emlab.berkeley.edu/users/groland/pubs/The Russian_Economy in the Year_2 005.pdf

Rutherford, Donald, 1992, Dictionary of Economics (New York, Routledge). 
Sachs, Jeffrey D. and Andrew M. Warner, 1995 (revised 1997 and 1999), "Natural resource abundance and economic growth," National Bureau of Economic Research Working Paper No. 5398 (Cambridge, Mass: NBER). ,2001, "The Curse of Natural Resources," European Economic Review, Vol. 45, No. 4-6, pp. 827-38.

Sala-i-Martin, Xavier and Arvind Subramanian, 2003, "Addressing the natural resource curse: an illustration from Nigeria," National Bureau of Economic Research Working Paper No. 9804 (Cambridge, Mass: NBER).

Sosunov, Kirill and Oleg Zamulin (2006a), "Can Oil Prices Explain the Real Appreciation of the Russian Ruble in 1998-2005?”,CEFIR/NES Working Paper No. 83 (Moscow: Center for Economic and Financial Research at New Economic School). , (2006b), “The Inflationary Consequences of Real Exchange Rate Targeting via Accumulation of Reserves," BOFIT Discussion Paper No. 11 (Helsinki: Bank of Finland Institute for Economies in Transition).

Spatafora, Nicola and Emil Stavrev, 2003, "The Equilibrium Exchange Rate in a Commodity Exporting Country: The Case of Russia,” IMF Working Paper 03/93 (Washington: International Monetary Fund).

Standard and Poor's, 2005, “Russia: Facing 'Dutch Disease' Reform,” June 6. ,2006, "Avoiding the hydrocarbons habit is vital for sovereign ratings on Russia," CreditWeek, July.

Tornell, Aaron and Philip Lane, 1999, "Voracity and Growth," American Economic Review, Vol. 89, pp. 22-46.

Torvik, Ragnar, 2001, "Learning by Doing and the Dutch Disease," European Economic Review, Vol. 45, No. 2, pp. 285-306.

Wei, Shang-Jin and Yi Wu, 2001, "Negative Alchemy? Corruption, Composition of Capital Flows, and Currency Crises," National Bureau of Economic Research Working Paper 8187 (Cambridge, Mass: NBER).

Westin, Peter, 2004, "Dutch Disease: Diagnosing Russia” (Moscow: ATON Capital).

World Bank, 2004, Russian Economic Report, No. 7 (Washington: The World Bank). Available via the Internet: http://ns.worldbank.org.ru , 2005a, "From Transition to Development. A Country Economic Memorandum for the Russian Federation" (Washington: The World Bank). Available via the Internet: http://ns.worldbank.org.ru 
, 2005b, Russian Economic Report, No. 11 (Washington: The World Bank). Available via the Internet: http://ns.worldbank.org.ru

Younger, Stephen D., 1992, “Aid and the Dutch Disease: Macroeconomic Management When Everybody Loves You,” World Development, Vol. 20, No. 11, pp. 1587-97. 